\title{
SOME REFLECTIONS ON TRANSLATING THE PALI TEXTS: LITERARY CONVENTIONS, BUDDHIST THOUGHT, CULTURAL BACKGROUND AND TEXTUAL HISTORY
}

\author{
KUAN Tse-fu \\ College of General Studies, Yuan Ze University \\ 135 Yuan-Tung Road, Chung-Li, Taoyuan, Taiwan \\ e-mail: jeformosa@yahoo.com
}

\begin{abstract}
For over a century many Buddhist texts in Pali have been translated into English, the four main Nikāyas at least twice. Significant improvements have been made in regard to English translations of Pali texts. This paper provides five case studies that illustrate the problems and complexities involved in translating Pali texts. Examples are taken from four suttas of the Anguttara Nikāya. Various issues are addressed using textual and contextualised analyses. I attempt to offer solutions to some problems related to translating the Pali through different approaches, including style, philology, history, Buddhist thought and inter-religious relation.
\end{abstract}

Key words: Buddhist literature, early Buddhism, Pali, Sanskrit, Chinese, translation.

\section{Introduction}

For over a century many Buddhist texts in Pali have been translated into English. The four main Nikāyas have been translated into English at least twice. Significant improvements have been made in regard to English translations of Pali texts. The aim of this study is to deal with some issues connected to the existing translations of the Anguttara Nikāya. There are two complete English translations of this collection:

1. The Book of the Gradual Sayings, 5 vols., translated by F. L. Woodward (I, II, V) and E. M. Hare (III, IV), published by the Pali Text Society from 1932 to 1936.

2. The Numerical Discourses of the Buddha: A Translation of the Anguttara Nikāya, translated by Bhikkhu Bodhi. Boston: Wisdom Publications, 2012.

There are two partial English translations of the Anguttara Nikāya: 
1. Numerical Discourses of the Buddha: An Anthology of Suttas from the Anguttara Nikāya, translated by Nyanaponika Thera and Bhikkhu Bodhi. New Delhi: Vistaar Publications, 2000 (Kandy: Buddhist Publication Society, 1999).

2. Handful of Leaves, Volume Three: An Anthology from the Anguttara Nikâya, translated by Bhikkhu Thanissaro. USA: The Sati Center for Buddhist Studies, 2003.

The five case studies provided below draw on four suttas in the first two volumes of the Anguttara Nikāya published by the Pali Text Society (Ee I, II). Neither of the two partial translations includes any of these four suttas. Therefore, I will only mention the translations by F. L. Woodward $(1932,1933)$ and Bhikkhu Bodhi (2012). As many would agree, however excellent a translation may be, there is always room for improvement. In this paper various issues are addressed using textual and contextualised analyses. I attempt to offer solutions to some problems related to translating the Pali through different approaches, including style, philology, history, Buddhist thought and inter-religious relation.

\section{Literary Conventions of Pali Suttas}

\subsection{Vocative in Direct Speech}

Sutta 80 in the Book of the Threes in the Ariguttara Nikāya (AN 3:80, I 228) has the following sentence with variant readings:

Ee I 228, 19-21:

Evam vutte āyasmā Ānando [āyasmantam Udāyim] etad avoca: 'Lābhā vata me, suladdham vata me, yassa me satthā evam mahiddhiko evam mahānubhāvo'ti.

Be I 229, 13-15:

Evam vutte āyasmā Ānando (āyasmantam Udāyim) etad avoca: 'Lābhà vata me, suladdham vata me, yassa me satthā evam mahiddhiko evam mahānubhāvo'ti.

Se I 297, 4-6:

Evam vutte āyasmā Ānando etad avoca: 'Lābhā vata me, suladdhạ̣ vata me, yassa me satthā evam mahiddhiko evam mahānubhāvo'ti.

Ce I 404, 13-14:

Evam vutte āyasmā Ānando Bhagavantam etad avoca: 'Lābhā vata me, suladdham vata me, yassa me satthā evam mahiddhiko evam mahānubhāvo'ti.

In this sentence, Ce has Bhagavantam. Ee and Be have āyasmantam Udāyim and both put it in brackets, thereby indicating both editors' uncertainty. By contrast, Se is the shortest and has neither Bhagavantam nor āyasmantam Udāyim. Woodward (1932: 208) presumably follows the Ee reading, but ignores the brackets, thus he translates: 
' $\ldots$ the venerable Ānanda exclaimed to the venerable Udāyin: ...'. Bodhi (2012: 314) reads with $\mathrm{Ce}$ and renders the above whole sentence as follows:

When this was said, the Venerable Annanda said to the Blessed One [Bhagavantam]: "It is my good fortune! I am very fortunate that my Teacher is so powerful and mighty." (The Pali word in square brackets is mine.)

According to the literary conventions of Pali suttas, when person A speaks to person $\mathrm{B}$, person A normally addresses person $\mathrm{B}$ in the vocative near the beginning of person A's direct speech. If Woodward's translation is right, Ānanda would address Udāyin as 'āvuso Udāyi' (friend Udāyin, e.g. AN III 322, where Ānanda talks to Udāyin). If Bodhi's translation is right, Ānanda would address the Blessed One (Bhagavant) as 'bhante' (venerable sir, e.g. AN I 223-228). Such vocatives, however, are absent from the words uttered by Ānanda. This fact indicates that Ānanda is addressing no one. Therefore, Se has the correct reading; the correct translation would be something like:

When this was said, the Venerable Ānanda said: 'It is my good fortune!

I am very fortunate that my Teacher is so powerful and mighty.'

The Japanese translation by Wogihara (1935: 372), ‘是の如く語られたる時に具壽 阿難は唱へて曰く——鳴呼我に利あり......’, which renders neither àyasmantam Udāyim nor Bhagavantam, is the first translation to be based on the correct reading as far as I am aware. ${ }^{1}$ As Wogihara points out in the prefatory note (凡例) to his translation of the Anguttara Nikaya, his translation is based on the Pali Text Society edition (Ee) by Richard Morris, but he also consults the Siamese edition (Se).

\subsection{Waxing Syllable Principle}

Sutta 63 in the Book of the Threes in the Anguttara Nikāya (AN 3:63) contains an exposition of three kinds of 'high and big beds'. Of the three, the 'brahmic high and big bed' is explained using the formula of the four 'brahma abodes' (brahma-vihära), which reads (trans. Bodhi 2012: 275):

... I dwell pervading one quarter with a mind imbued with loving-kindness, likewise the second quarter, the third quarter, and the fourth quarter. Thus above, below, across, and everywhere, and to all as to myself [sabbattatāya], I dwell pervading the entire world with a mind imbued with loving-kindness, vast, exalted, measureless, without enmity, without ill will. [The same is said of compassion, empathetic joy and equanimity.] ${ }^{2}$

${ }^{1}$ I can only read English, Japanese and Chinese translations. My ignorance of German, French, Italian, Thai, Sinhalese, Burmese and so on has prevented me from referring to the possibly existing translations in these languages.

${ }^{2}$ AN I 183: so mettāsahagatena cetasā ekam disam pharitvā viharāmi tathā dutiyam tathā tatiyam tathā catuttham. Iti uddham adho tiriyam sabbadhi sabbattatāya sabbāvantam lokam 
Here is a problematic word, sabbattatāya. Bodhi (2012: 275) renders it as 'to all as to myself' based on the commentarial tradition (see Section 3). Woodward (1932: 166) translates it as 'for all sorts and conditions'.

As Wang (2008: 17) points out, according to Edgerton's Buddhist Hybrid Sanskrit Dictionary, sabbattatāya corresponds to sarvatratāye in the Mahāvastu, ${ }^{3}$ a Buddhist Hybrid Sanskrit text. Edgerton states that sarvatratāye means 'altogether, in every way' and is apparently the instrumental of sarvatra-ta ${ }^{4}$, a noun formed by attaching the abstract suffix -t $\bar{a}$ to sarvatra, which is an adverb meaning 'everywhere' (MW 1189 s.v. sarvatra). In his translation of the Mahāvastu, Jones (1956: 209) renders sarvatratāye as 'everywhere'. In other words, adding the abstract suffix $-t \bar{a}$ inflected in the instrumental case, -tàye, does not change the meaning of sarvatra.

That sabbattatāya means 'everywhere' can be reinforced in view of a stylistic feature of Pali sutta literature. As Allon (1997: 364) observes, the authors of Pali canonical sutta texts 'tended to expand the wording and create strings or sequences of similar word elements and units of meaning wherever possible'. The Pali phrase sabbadhi sabbattatāya sabbāvantam lokam, which can be rendered literally as 'everywhere, ${ }^{5}$ everywhere, the entire world', is a sequence of synonymous word elements typical of Pali canonical texts. This case also conforms to the waxing syllable principle suggested by Allon (1997: 191): 'as the sequence progresses the syllable length of each subsequent element may be equal to or greater than what precedes it.' In accord with this principle, our phrase consists of a string of three adverbial expressions: sabbadhi has 3 syllables, sabbattatāya has 5 syllables, and sabbāvantam lokam has 6 syllables.

\section{How Closely Should We Follow the Commentarial Tradition? Sanskrit and Chinese Parallels as Alternative Solutions}

When we encounter difficulties in translating the Pali suttas, it is often useful to consult the commentaries (Atthakatha $)$ on the canonical texts by Buddhaghosa ( 5 th century CE) and his Visuddhimagga which is closely connected to the Nikayya commentaries and 'seems to quote from the old Atthhakathā much more extensively than the extant commentaries do' as von Hinüber (1997: 125) remarks. While affirming the values of the commentaries, Norman (2004: 69-72) suggests that the commentarial tradition sometimes does not agree with philology and is not always correct in interpreting the Nikāyas. T. W. Rhys Davids and William Stede (PED 620 s.v. vitakka)

mettāsahagatena cetasā vipulena mahaggatena appamānena averena avyāpajjhena pharitvā viharāmi. karun̄āsahagatena ... muditāsahagatena ... upekkhāsahagatena ...

${ }^{3}$ Mvu III 213: yad ihaikatyo karunāparena cetasā ekān diśäm spharitvopasampadya viharati ... tathā dvitīyam tathà tritiyam tatha caturtham. iti ürdhvam adho tiryak sarvehi sarvatratāye sarvāvantam lokam spharitvopasampadya viharati.

${ }^{4}$ BHSD 584 s.v. sarvatratāye, adv. (app. instr. of *sarvatra-tā; = Pali sabbattatāya or sabbatthatāya ...), altogether, in every way. For the instrumental ending -äye, see BHSG p. 64, § 9.37.

${ }_{5}^{5}$ Sabbadhi also means 'everywhere'. See PED 680 s.v. sabba. 
also caution us: 'The explanations of Commentators are mostly of an edifying nature and based more on popular etymology than on natural psychological grounds.'

Moreover, the Pali commentaries and subcommentaries are separated from the sutta texts by more than seven or eight centuries. They are even later than many Chinese translations of the Indic texts. The four Agamas in Chinese translation from various traditions (see Section 6.3 below) correspond to the four main Nikāyas of the Theravāda tradition. They were translated from Prakrit languages or Sanskrit into Chinese in the 4th and 5th centuries CE. Sharf (2002: 12) says:

Our appraisal of the accuracy of Chinese translations and interpretations is, therefore, compromised by our own distance from the Indic originals. Indeed, we are at a far greater temporal and geographic remove from the Indian sources than were the Chinese of the Six Dynasties and the T'ang.

It is not sensible to confine our research to the Pali sources, which just belong to a single tradition of the Theravāda school. The (Hybrid) Sanskrit and Chinese sources from different traditions may cast valuable light on the issues of translating Pali texts into English. This paper (above and below) provides several examples of how to better translate the Pali words by taking Sanskrit and Chinese versions into account without simply relying on the Pali commentarial literature.

In Section 2.2 we have discussed the meaning of sabbattataya in AN 3:63 (I 183). Bodhi (2012: 275) renders it as 'to all as to myself', presumably following the interpretation in the Visuddhimagga (cf. Wang 2008: 20), which is also found in Buddhaghosa's commentary on the Vibhanga, an Abhidhamma text: ${ }^{6}$

Equally (sabbattatāya): to all [sabbesu] classed as inferior, medium, superior, friendly, hostile, neutral, etc., just as to oneself [attatāya]; equality with oneself (atta-samatā) without making the distinction 'This is another being', is what is meant. ' (Trans. Ñānamoli 1975: 334; Pali words in square brackets are mine $-\mathrm{TK}$.)

Accordingly, the word sabbattatāya is construed as a compound in the locative case, comprising sabbesu (to all) and attatâya (to oneself); the combination of the two words would yield a new meaning: 'equality between all and oneself'. This interpretation sounds somewhat far-fetched in terms of etymology, although it is positive in terms of edification. ${ }^{8}$ In the Visuddhimagga this is not the only case in which edify-

${ }^{6}$ von Hinüber (1997: 151) suggests that Buddhaghosa could be the initiator rather than the composer of the Abhidhamma commentaries.

${ }^{7}$ Vism IX.47 and Vibh-a 377: Sabbattatāya ti sabbesu hina-majjhimukkatțha-mitta-sapattamajjhattādi-ppabhedesu attatāya; ayam parasatto ti vibhāgam akatvā atta-samatāaya ti vuttam hoti.

${ }^{8}$ For example, Heim (2017: 181) says: 'This is an image of likeness or sameness with the other that counters our usual tendencies to classify and rank others ... a resource for cultivating the affective conditions helpful for constructing an ethic of social equality and justice.' She does not notice the fallacy of the commentarial gloss. 
ing concerns override philology, and recourse is made to folk etymology. In his discussion of the word nirvāna/nibbāna, Hwang (2006: 12) notes:

Buddhaghosa also ignored the original etymological meaning of the word, the extinction of the triple fires of passion, hatred and delusion, and presented a different explanation of nirvāna based on vāna ... derived from $\sqrt{ } v \bar{a}$ (to weave) in his Visuddhimagga: It is called nibbāna (extinction) because it has gone away from (nikkhanta), has escaped from (nissata), is dissociated from, craving, which has acquired in common usage the name 'fastening (vāna)' ...

As mentioned above, the Pali phrase sabbadhi sabbattatāya sabbāvantam lokam can be rendered literally as 'everywhere, everywhere, the entire world'. The Buddhist Hybrid Sanskrit counterpart sarvehi $i^{9}$ sarvatratāye sarvāvantam lokam in the Mahāvastu also means the same and Jones (1956: 209) translates it as 'everywhere, the whole wide world' without repeating 'everywhere'. Similarly, Dānapāla (Shihu 施護, 10th century CE) translates a corresponding phrase in the *Mahā-samgìti Sütra (T 12, Da jifamen jing 大集法門經) as 'in all places, all the world', ${ }^{10}$ which was probably translated from a (classical) Sanskrit equivalent for sarvehi sarvatratāye sarvāvantam lokam.

The interpretation of sabbattatāya in the Visuddhimagga can distinguish this word from sabbadhi and therefore avoid the awkward repetition of 'everywhere', but this is unlikely to be what the original text intends to express. A better strategy of translating sabbadhi sabbattatāya is to render these two words as one word 'everywhere', just as Jones and Dānapāla did. Or alternatively, we can use two synonyms to translate sabbadhi sabbattatāya, for example, 'everywhere, in all places'.

\section{Rivalry between Buddhism and Other Religions}

The foregoing AN 3:63 (I 180-185) records the Buddha's visit to a village called Venāgapura as follows. When he had just arrived, a good report about him was circulated, so the brahmin householders went to see him. A brahmin of the Vaccha clan, or Vacchagotta, praised the Buddha thus (in brief):

It is amazing how Master Gotama's faculties are tranquil and the colour of his skin is pure and bright. ... Whatever high and big beds there are - that is, a sofa, a divan ... with a canopy above and red bolsters at both ends-Master Gotama surely gains at will, without trouble or difficulty. (Translation mostly follows Bodhi 2012: 273-274.)

Then the Buddha said that for those who have gone forth, it is difficult to obtain such high and big beds (uccā-sayana-mahä-sayana), and if such beds are obtained, they are

${ }^{9}$ BHSD 586 s.v. sarvehi, adv. (app. instr. pl. of sarva, but corresp. to Pali sabbadhi, of obscure ending), altogether.

${ }^{10}$ T I 228c: 於一切處、一切世界。 
not allowed. As a witty riposte to the brahmin's backhanded compliment, the Buddha declares in a metaphorical way that he has access at will to three kinds of 'high and big beds':

dibbạ̣ uccā-sayana-mahā-sayanam, brahmam uccā-sayana-mahāsayanam, ariyam uccā-sayana-mahā-sayanam (AN I 182).

Woodward (1932: 165) translates: 'They are the high, broad couch celestial, that which is sublime, and the high, broad couch of the Ariyans.' Bodhi (2012: 274) translates: 'The celestial high and luxurious bed, the divine high and luxurious bed, and the noble high and luxurious bed.' Neither of these translations conveys the meaning that the Buddha wants to express in a particular religious context. The Buddha lists the three kinds of 'high and big beds' in such a hierarchy that whereas Brahmā trumps the gods, he is however trumped by the Buddhist noble ones according to Gombrich (2009: 192).

This sutta presents the Buddha's denial of brahmins' claim to hierarchical superiority and hence the supremacy of their religion, Brahmanism. In the early Upani$s a d \mathrm{~s}$, Brahman has a variety of meanings, including 'the ultimate and basic essence of the cosmos' (Olivelle 1998: 26-27). At a later stage the abstract Brahman, a neuter word, came to be personified as the deity Brahmā, a masculine word, seen as the creator of the universe (Brockington 1996: 54-55). Along with this theistic trend, as Gombrich (2001: 96) observes, in the early Buddhist texts, the gods borrowed from the Indian cultural background are all called deva and inhabit heavens called devaloka, which form part of the sensual-desire realm (kāma-dhātu). In contrast to the 'devas proper' (as Harvey 2013: 34 puts it) of the sensual-desire realm, Brahmā is above this realm and inhabits the fine-material realm (rüpa-dhātu). Gombrich (2001: 96) points out that the early Buddhist texts follow the Bṛad-äranyaka Upanișad (6.2.15-16) in putting Brahmā in a special category, above the gods (deva).

When the Buddha refers to the first two kinds of 'high and big beds', i.e. dibbam uccā-sayana-mahā-sayanam and brahmam uccā-sayana-mahā-sayanam, the adjectives dibba and brahma allude respectively to gods (deva) and Brahmā, with the latter higher than the former, according to Buddhist cosmology based on the Upanisad mentioned above. As to the third kind of 'high and big bed', ariyam uccāsayana-mahā-sayanam, the adjective ariya, usually rendered as 'noble', means almost the same as 'Buddhist' (DOP I 235). When ariya is used as a noun, as Buswell and Lopez (2014: 64) say, it is a 'term appropriated by the Buddhists from earlier Indian culture to refer to its saints and used technically to denote a person who has directly perceived reality and has become a "noble one", The Buddha clearly talks about the three kinds of 'high and big beds' in a sequence that denotes a hierarchy: gods (deva, adjective dibba) are subordinate to Brahmā (adjective brahma), while Brahmā is subordinate to Buddhist saints or noble ones. In other words, Buddhism is superior to Brahmanism and other religions. The following table shows the three adjectives in sequence expressed by the Buddha as religions in rank order and how the three adjectives are translated by Woodward and Bodhi mentioned above. 


\begin{tabular}{|l|l|l|l|}
\hline Adjectives & dibba & brahma & ariya \\
\hline Buddha & of gods $(\operatorname{deva})$ & of Brahmā & of Buddhist noble ones \\
\hline Woodward & celestial & sublime & of the Ariyans \\
\hline Bhikkhu Bodhi & celestial & divine & noble \\
\hline
\end{tabular}

Neither of the two English translations captures the metaphorical implications of the Buddha's discourse. A better translation could be what is suggested by Gombrich (2009: 192): 'divine' for dibba, 'brahmic' for brahma, and 'noble' for ariya.

In the Buddha's exposition, (1) the divine 'high and big bed' is associated with the four jhänas, (2) the brahmic 'high and big bed' is associated with loving-kindness, compassion, empathetic joy and equanimity, referred to as brahma-vihäras in other texts (e.g. AN I 243, Sn 151), and (3) the noble 'high and big bed' is associated with the knowledge of liberation from greed, hatred and delusion. Anālayo (2015: 19) points out:

The early Buddhist texts in fact recurrently refer to the practice of the jhānas and of the brahmavihāras as pre-Buddhist forms of practice. This stands in contrast to the development of liberating insight, which the same texts clearly consider the specific discovery of a Buddha.

This echoes the rationale behind the exposition of the three kinds of 'high and big beds'. The Buddha appropriates the terminology and conception of Brahmanism, and sets them within a new framework that fits into Buddhist doctrines. An ideal translation should be able to accommodate this multi-religious phenomenon.

\section{Translation Considered within a Broader Context of Buddhist Thought}

A passage in sutta 29 of the Book of the Fours in the Ariguttara Nikayya (AN 4:29) reads:

Cattār' imāni bhikkhave dhammapadāni aggañ̃nāni rattaññanni vam-

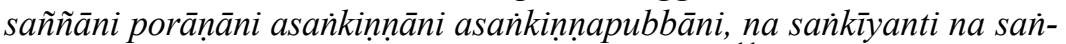
kīyissanti, appatikutțhāni samaṇehi brāhmanehi ${ }^{11}$ viññūhi. Katamāni cattāri? Anabhijjhā bhikkhave dhammapadam aggañnam rattañnam vaṃsañ̃am porānam ... Avyāpādo ... Sammāsati ... Sammāsamādhi ... (AN II 29)

Bhikkhu Bodhi (2012: 416) translates this passage as follows:

\footnotetext{
${ }^{11}$ I read with Be I 337, 24, Se II 37, 16 and Ce II 58, 19. Ee II 29, 7-8 reads samanehi vā brāhmanehi vā.
} 
Bhikkhus, there are these four Dhamma factors, primal, of long standing, traditional, ancient, unadulterated and never before adulterated, which are not being adulterated and will not be adulterated, which are not repudiated by wise ascetics and brahmins. What four? (1) Non-longing [anabhijjha $\bar{a}$, non-covetousness] is a Dhamma factor, primal, of long standing, traditional, ancient ... (2) Good will [avyāpāda, 'non-malice'] ... (3) Right mindfulness ... (4) Right concentration ...

Here Bhikkhu Bodhi renders dhamma-padāni as 'Dhamma factors'. Similarly, Woodward (1933: 32) translates this compound as 'factors of Dhamma'. Bodhi (2012: 1684 note 683) implies that his translation is in accordance with the commentary's explanation of this compound as 'portions of Dhamma' (Mp III 61: dhammakotthāsā). 'Dhamma-pada' is the title of a famous Buddhist text and is translated by Norman (2000: 1) as 'The Word of the Doctrine' and by Tin (1990:1) as 'Path of the Buddha's Teaching'.

Besides 'factor', 'word' and 'path', pada has many other meanings, one of which is 'track' or 'footprint'. 12 The foregoing sutta passage is partly quoted in an Abhidharma text of the Sarvāstivādins, the Saṃgitiparyāya (T 1536, Ji yimen zu lun 集異門足論), preserved in Chinese translation. This Abhidharma text was translated by Xuanzang 玄焋 (602?-664), an eminent scholar monk who studied in India for 12 years ${ }^{13}$ in the 7 th century CE, when the Sanskritisation of Buddhist texts had been completed (Norman 2006: 124). Here Xuanzang translates the Sanskrit equivalent for dhamma-pada as fa ji 法跡 ${ }^{14}$ 'Dhamma footprint' (T XXVI 395a). In my opinion, this rendering makes better sense on the following grounds.

According to some suttas, the Buddha did use the simile or metaphor of 'footprint' (pada) to describe the Dhamma that he discovered and preached. For example, the Mahāhatthipadopama Sutta of the Majjhima Nikāya states:

Friends, just as the footprints of all living beings that walk fit into the footprint of the elephant, and the elephant's footprint is declared to be their chief by reason of its size, so too, all wholesome states can be included in the Four Noble Truths. ${ }^{15}$ (Translation mostly follows Ñānamoli and Bodhi 2001: 278.)

As Rahula (1959: 16) points out, the heart of the Dhamma lies in the Four Noble Truths, which the Buddha expounded in his very first sermon, namely the Dhammacakkappavattana Sutta, the Discourse on 'Setting in Motion the Wheel of the Dham-

${ }^{12}$ PED 408 s.v. pada: footstep, track ... apada ... trackless, leaving no footprint.

${ }^{13}$ From the 5th to 17th year of the Zhenguan 貞觀 era (ca 631-643), see FD 2025.

${ }^{14}$ While the Taishō edition reads 迹 (T XXVI 395a), the Ming edition reads 跡 as given in footnote 4 at T XXVI 395. The two characters are alternative forms. See EDC Vol. VIII, p. 1569, s.v. 跡: 與迹同. 跡 only means 'footstep' as a noun (EDC Vol. VIII, p. 1569, s.v. 跡). 迹 as a noun can mean 'footstep', 'path', etc. (EDC Vol. IX, p. 34, s.v. 迹).

${ }^{15}$ MN I 184: Seyyathāpi āvuso yāni kānici jañgamānam pānānam padajātāni sabbāni tāni hatthipade samodhānam gacchanti, hatthipadam tesam aggam akkhāyati yad idam mahantattena; evam eva kho āvuso ye keci kusalā dhammā sabbe te catusu ariyasaccesu sañgaham gacchanti. 
ma' (SN V 420-424). In the Mahāhatthipadopama Sutta cited above, the Four Noble Truths, i.e. the Dhamma, is compared to the elephant's footprint (pada).

Using the same simile, sutta 48:54 of the Samyutta Nikāya states:

Bhikkhus, just as the footprints of all living beings that walk fit into the footprint of the elephant, and the elephant's footprint is declared to be their chief by reason of its size, so too, among the steps [padāni] that lead to enlightenment, the faculty of wisdom is declared to be their chief. $^{16}$ (Trans. Bodhi 2000: 1697-1698.)

This sutta enumerates the five faculties - faith, energy, mindfulness, concentration and wisdom - as the steps that lead to enlightenment. Here Bhikkhu Bodhi translates padāni as 'steps' rather than 'factors'. The commentary (Spk III 248) rephrases padāni as dhamma-padāni, which Bodhi (2000: 1938, note 239) renders as 'Dhammasteps' instead of 'Dhamma factors' mentioned above. This way of understanding and translating dhamma-padāni suits the case of AN 4:29 better. AN 4:29 expounds cattāri dhamma-padāni, which may well be rendered as 'four Dhamma footprints'. This is possibly a metaphorical expression involving 'four-footed animals'.17

Moreover, according to sütra 287 of the Samyukta Ägama (SĀ) extant in Chinese translation, the Buddha says the following to the monks:

Then it occurred to me: 'I have discovered (lit. obtained) the path of the ancient seers, the road of the ancient seers, the ancient seers' footprints ( $j i$ 跡) on the path; the ancient seers left behind (lit. left from) these footprints, which I now follow.' Suppose someone would travel in a wilderness ... So now I have discovered the path of the ancient seers, the road of the ancient seers, the ancient seers' footprints ... which I have discovered and followed, that is, the Noble Eightfold Path. ${ }^{18}$

It is noteworthy that in the Dhammacakkappavattana Sutta the Buddha refers to the Noble Eightfold Path as what he has awakened to. Since this Eightfold Path is the last truth of the Four Noble Truths, i.e. the Dhamma, and this sutta is the Buddha's first sermon called 'Setting in Motion the Wheel of the Dhamma', the Noble Eightfold Path also represents the Dhamma. In sütra 287 of SA cited above, the Dhamma is metaphorically referred to as the footprints which were left and followed by the ancient seers and then discovered by the Buddha who also followed them. Another version of this sütra entitled the *Pratītyasamutpāda-āryamārga Sütra (T 714, Yuanqi shengdao jing 緣起聖道經) contains the following passage:

${ }^{16}$ SN V 231: Seyyathāpi bhikkhave yāni kānici jañgamānam pāṇānam padajātāni sabbāni tāni hatthipade samodhānam gacchanti, hatthipadam tesam aggam akkhāyati, yad idam mahantattena; evam eva kho bhikkhave yāni kānici padāni bodhàya samvvattanti, paññindriyam tesam aggam akkhāyati.

${ }^{17} \mathrm{I}$ am grateful to the second reviewer for this suggestion.

${ }^{18} \mathrm{~T}$ II 80c: 我時作是念：「我得古仙人道、古仙人逕、古仙人道跡，古仙人從此跡 去, 我今隨去。」譬如有人遊於曠野... 今我如是得古仙人道、古仙人逕、古仙人跡...我得隨 去, 謂八聖道。 
Suppose someone would travel in a wilderness ... So too, I have now
realised the ancient path, the ancient road, the ancient footprints ( $j i$ 跡)
walked, travelled upon by the ancient seers. What is the ancient path,
the ancient road, the ancient footprints walked, travelled upon by the
ancient seers? It should be understood to be the Noble Eightfold Path.

This passage resembles part of the passage quoted above from sütra 287 of SĀ. Both versions mention $j i$ 跡, footprint, which also appears in the foregoing Samgittiparyāya translated by Xuanzang. Since the $j i$ 跡 that appears in the Samgitiparyāya is in a quotation from a Sarvāstivādin sūtra parallel to AN 4:29, this Chinese character was no doubt translated from pada in dharma-pada, the Sanskrit equivalent for dhamma-pada in Pali. The Chinese SA was translated by Gunabhadra 求那跋陀羅 between 435 and 443 CE (Bingenheimer 2011: 1) from a Sanskrit original (de Jong 1981: 108). The * Pratītyasamutpāda-āryamārga Sūtra was translated by Xuanzang in the 7th century when the Sanskritisation of Buddhist texts had been completed (see above). In these two texts, $j i$ 跡 is also likely to be a rendering of pada, 'footprint', in Sanskrit. ${ }^{20}$

Sütra 287 of SĀ has a Pali counterpart in the Samyutta Nikāya (SN II 104107). It makes no mention of pada, 'footprint', in the following account:

Suppose, bhikkhus, a man wandering through a forest would see an ancient path, an ancient road travelled upon by people in the past ... So too, bhikkhus, I saw the ancient path, the ancient road travelled by the Perfectly Enlightened Ones of the past. And what is that ancient path, that ancient road? It is just this Noble Eightfold Path. ${ }^{21}$ (Trans. Bodhi 2000: 603.)

Here we have three versions of a sutta passage. The Pali version belongs to the Theravāda. The Samyukta Āgama (SĀ) in Chinese translation is ascribed to the Sarvāstivāda (Kumoi 1963: 248; Ui 1965: 136; Yinshun 1994: 97; Hiraoka 2000: 501) or more specifically the Mūlasarvāstivāda (Lü 1963: 242; Enomoto 1984a: 1071; Enomoto 1984b: 99; Mizuno 1996: 373-375; Hiraoka 2003; Dhammadinnā 2012: 68). The school affiliation of the *Pratītyasamutpāda-āryamārga Sūtra is unknown. Two out of the three versions allegorise the Noble Eightfold Path as the footprints left behind and followed by the ancient seers $\left(\right.$ 仙, * $\left.{ }_{r} s{ }^{i}\right)$, ${ }^{22}$ whereas one version does not. It is hard to assert which version is closer to the original. But it seems plausible to liken the Noble Path, or the Dhamma, to the footprints left behind by the former Buddhas when we take AN 4:29 into account.

${ }^{19} \mathrm{~T}$ XVI 828c: 譬如有人遊行曠野...我亦如是, 今已證得舊道、舊徑、舊所行跡, 古昔諸仙嘗所遊履。何等名為舊道、舊徑、舊所行跡, 古昔諸仙嘗所遊履? 當知即是八支聖 道。

${ }^{20}$ Cf. SJD 732 s.v. pada.

${ }^{21}$ SN II 105-106: Seyyathāpi bhikkhave puriso arañ̃̃e pavane caramāno passeyya purāṇam maggam purānañjasam pubbakehi manussehi anuyātam ... Katamo ca so bhikkhave purānamaggo purānañjaso pubbakehi sammāsambuddhehi anuyāto? Ayam eva ariyo ațthañgiko maggo.

${ }^{22}$ A r̦și (Pali isi) can refer to a Buddha. See DOP I 379. 
First, this sutta enumerates four dhamma-padas: (1) non-covetousness, (2) non-malice, (3) right mindfulness, and (4) right concentration. The last two dhammapadas are exactly the last two divisions of the Noble Eightfold Path. The first two dhamma-padas constitute 'right intention', the second division of the Noble Eightfold Path, according to the Saccavibhanga Sutta of the Majjhima Nikāya. ${ }^{23}$ Therefore, what the four dhamma-padas refer to is the Noble Path, so padas can be rendered as 'footprints' according to the above discussion. At first glance, translating pada as 'path' seems also to fit in with this context, but it would follow that cattāri dhammapadāni should be rendered as 'four Dhamma paths'. Early Buddhism, however, only talks about one path to nirvana/enlightenment, ${ }^{24}$ albeit in different expressions such as 'Noble Eightfold Path' (ariyo atthangiko maggo, singular), rather than 'four paths' or 'eight paths' and so forth. ${ }^{25}$

Second, in the sutta AN 4:29, the compound dhamma-padāni is qualified by the phrase 'primal, of long standing, traditional, ancient' (aggaññāni rattañ̃āani vamsañ̄āni porānāni), which resonates with the metaphor of footprints (*pada) left behind by the ancient seers, namely the former Buddhas in ancient times. The Buddha who delivered this discourse (sutta) had found those footprints and followed them, thereby reaching the goal of nirvana.

Consequently, it is advisable to imitate Xuanzang's rendering ' $f a$ ji 法跡' and translate dhamma-pada as 'Dhamma footprint', with the Pali seen as a kammadhāraya compound. The expression 'Dhamma footprints that are primal, of long standing, traditional, ancient' can be understood to mean that the Dhamma, i.e. the Path, is ancient and long-standing, and has been rediscovered and followed again and again by many Buddhas, just as the ancient and long-standing footprints have been left by one person and followed by another repeatedly.

\section{Philological, Cultural and Historical Approaches}

Sutta 37 in the Book of the Threes in the Anguttara Nikâya (AN 3:37) contains a puzzling word. It appears seven times in similar contexts such as the following:

On the eighth of the fortnight, the ministers and assembly members of the four great kings wander over this world, [thinking]: 'Are there many people who behave properly towards their mother and father, behave

${ }^{23}$ MN III 251: Katamo c' āvuso sammāsañkappo? Nekkhammasà்kappo, avyāpādasànkappo, avihimsāsañkappo (And what, friends, is right intention? Intention of non-desire, intention of non-malice, intention of non-harming).

${ }^{24}$ E.g. MN I 73: nibbāna-gāmiñ ca maggam; MN III 6: nibbāna-gāmi-maggo; SN IV 371: nibbāna-gāmiñ ca maggam. These occurrences of magga (path) are all in singular.

${ }^{25}$ Anālayo (2016) also argues for one path to liberation and refutes the 'two paths' theory advocated by some scholars. 
properly towards ascetics and brahmins, honour the elders of the family, observe the uposatha, patijaggar[e/o/a]nti, and make merits? ${ }^{26}$

This unclear word, patijaggar[e/o/a]nti, seems to be used in this sutta only, and not to be found in other texts (by searching CST). It has different readings in different editions:

1. pațijāgarenti in Ee I 142, 26-143, 25

2. pațijāgaronti in Be I 141, 13-142, 9 and Se I 182, 9-183, 8

3. patijāgaranti in Ce I 260, 13-37

Here we have 3 variant readings, none of which is found in the dictionaries ${ }^{27}$ available to me, except that the Ee reading preceded by a question mark is included as an entry in Edgerton's Buddhist Hybrid Sanskrit Grammar and Dictionary, Volume II: Dictionary:

BHSD 316 s.v. ? pațijāgareti $\left({ }^{\circ}\right.$ jāgarti $)=$ pratijāgarati, q.v., read by Senart by em. for (agnihotram) pațipākaroti ... Mv iii.148.20; 156.8, attends to, cares for; and amātyehi yathāṇattạ̣ sarvạ̣ patiyākṛtạ̣ (mss., Senart patijāgrtạ̣) ...

[pațipākaroti, so mss. for pațijāgareti, q.v.; or in Mv iii.161.7 mss. pațiyākṛtạ̣ (y could be graphic error for $\mathrm{p}$ ).

Accordingly, the manuscripts have patipākaroti, which was amended by Senart as patijaggareti in the context of 'attending to the sacred fire' (agnihotram patijāgareti), which is irrelevant to the context of our sutta.

Bodhi (2012: 1641 note 385) reads with Ce patijāgaranti and translates it as 'keep the extra observance days' (ibid. p. 237) following the commentary by Buddhaghosa. Bodhi (2012: 1641 note 385) translates the commentary (Mp II 233) thus:

Keeping the extra observance days (patijāgaranti) [my note: the commentary reads patijāgaronti, see below], in a single fortnight they do so by anticipating and following up (paccuggamanānugamana) the four uposatha days. Anticipating the uposatha of the fifth, they undertake the uposatha on the fourth; and following up, on the sixth ... the uposatha of the eighth ... seventh ... ninth ... Anticipating the uposatha of the fourteenth, they observe it on the thirteenth; and following up the uposatha of the fifteenth, they observe the uposatha at the beginning [of the next fortnight].

${ }^{26}$ AN I 142: Atthamiyam, bhikkhave, pakkhassa catunnam mahārājānam amaccā pārisajjā imam lokam anuvicaranti - kacci bahū manussā manussesu metteyyā petteyyā sāmaññā brahmañ̃āa kule jetțāpacāyino uposatham upavasanti pațijāgar[e/o/a]nti puññāni karontī ti.

${ }^{27}$ Even though patijaggaronti appears in CST based on Be, i.e. the digital version 4.0 of Chațtha Sangāyana Tipițaka, its built-in dictionary does not include an entry for pațijāgaroti or for the other two variants. 
This means that in each fortnight one may observe the uposatha on up to nine days, i.e. the 4th, 5th, 6th, 7th, 8th, 9th, 13th, 14th and 15th. ${ }^{28}$ According to our sutta, the uposatha days refer to the 8th, 14th and 15th days of each fortnight, so a month contains six uposatha days. ${ }^{29}$ Yinshun (1994: 113-114) points out that the ancient rule of six uposatha days per month gradually evolved into four uposatha days per month, ${ }^{30}$ presumably because observing the uposatha on two consecutive days, i.e. the 14th and 15th, would cause inconvenience to laymen's secular duties. It would conceivably cause even more trouble to laymen if they observed the uposatha on nine days each fortnight. In summary, the commentary's explanation sounds unconvincing. Furthermore, there is no etymological support for construing patijägaronti or the other variants as 'keeping the extra observance days'.

Woodward (1932: 126) says in a footnote that the Text reads patijāgarenti while the Commentary reads patijāgaronti. He translates it as 'keep the vigil' without explaining which reading he follows and why he renders it this way. The commentary on AN indeed reads pațijāgaronti and glosses: pațijāgarontī ti pațijāgara-uposatha-kammam nāma karonti (Mp II 233), which may be rendered as 'pațijāgaronti means: They really do the uposatha activity with watchfulness'. ${ }^{31}$ This seems to gloss patijaggaronti in such a way that the latter half of the word garonti is seen as the verb karonti (do, make), plural form of karoti (does, makes). Analysing patijāgaronti into patijāgara and karonti appears to be an instance of folk etymology (see Section 3 ). The subcommentary on $\mathrm{AN}^{32}$ also reads patijaggaronti, apparently duplicating the commentary's reading. Regarding patijägar[e/o/a]nti, Dr. Margaret Cone told me in an e-mail dated 27th June 2016: 'The word is listed in my dictionary as patijāgaroti. I think the PTS reading with enti is wrong. I have given a definition of "is awake, is watchful; keeps a vigil", but with a question mark!' The said dictionary is not yet published. Dr. Roderick S. Bucknell told me in an e-mail dated 16th June 2016: 'The German, however, is an early translation (by Nyanatiloka, decades earlier than Bhikkhu Bodhi's). It amounts to this: “... observe the fasting day, and do meritorious deeds." That is, it leaves 'pațijāgarenti' untranslated.'

${ }^{28}$ In an e-mail dated 11th March 2018 Dr. William Pruitt suggested: 'I think the idea is that a person can add on extra days - but it doesn't mean they have to all be added on.'

${ }^{29}$ The phrase 'six uposatha days' (六齋日, lit. six fasting days) appears in many texts in Chinese translation, e.g. the Mahāprajñāpāramitā Sütra (摩訶般若波羅蜜經, T 223) at T VIII 310c and the Five-Part Vinaya of the Mahīśāsaka school (彌沙塞部和䤈五分律, T 1421) at T XXII 106a.

${ }^{30}$ For the Theravāda, see PED $150-151$ s.v. uposatha: ' 1 st $, 8^{\text {th }}, 15^{\text {th }}, 23^{\mathrm{d}}$ (sic!)'. See also Nyanatiloka 1970: 187. For Northern Buddhism, see the Mūlasarvāstivāda Vinaya (T 1442, 根本說 一切有部毘奈耶) at T XXIII 842c-843a: 月八日 -十五日、二十三日、月盡日...四齋日 (four fasting days) ...

${ }^{31}$ The word patijaggara is not found in the dictionaries available to me. I tentatively translate it as 'watchfulness' because it looks like an (artificial) derivative of the Sanskrit verb pratijāgarti, ’jāgarati, meaning 'stay watchful' (see Section 6.2 below).

32 Anguttara-nikāya-țika (CST II 108): pațijāgaarontĩ ti pați pați jāgaronti (They constantly [lit. again and again] stay awake). I thank an anonymous reader for this reference. Here jaggaronti, plural form of $j \overline{a g a r o t} i$, is treated as a variant of the verb jägarati, which means 'is awake; is watchful' (DOP II 220). 
To sum up, it seems that modern translators are not sure about which of the three readings is correct, nor can they provide a cogent reason for their renderings of this word, or the word is simply left untranslated.

\subsection{Similar Phrases in Sanskrit Texts}

Since this puzzling word is not found in any Pali text except the sutta passage of the Anguttara Nikaya quoted above, the best way to solve the puzzle is probably to search Sanskrit texts for counterparts of this sutta passage. Unfortunately, even with the help of several scholars, no such passage has been found, but there are some Sanskrit phrases similar to 'uposatham upavasanti patijāgar[e/o/a]nti' (observe the uposatha, patijägar[e/o/a]nti) in our Pali passage. Below are two examples kindly provided by Dr. Ligeia Lugli:

1. The Bhikșuṇi-Vinaya of the Mahāsāmenghika-Lokottaravādin: nāsti bhaginīyo bhikșuñi-ovādako apramādena sampā̄detha āpattiñ ca poṣadham pratijägratha sa-gauravā ca bhavatha sthavirehi bhikșühi madhyehi navakehīti| (Roth 1970: 281)

Translation: Sisters, there is no bhikșuṇi instructor. You should strive diligently, keep the uposatha, and show respect for elder, middle-standing and junior bhikșus. ${ }^{33}$

2. The Poṣadhavastu of the Vinayavastvāgama of the Mūlasarvāstivādin: tasmād anujānāmi bhikșubhir adyāgrena nișadyā kriyā poṣadhaś ca pratijāgartavyah | (Poṣ-v 4, Hu-von Hinüber 1994)

Translation: Therefore, I prescribe that from this day onward the [meditative] sitting, [legal] procedures and uposatha should be kept by bhikșus.

The Sanskrit word poșadha is equivalent to the Pali uposatha. In these two Sanskrit texts, poșadha is governed by the transitive verb pratijagrati/pratijaggarti, which derives from prati- $\bigvee_{j} \bar{g} g r$ and probably means 'to keep', ${ }^{34}$ and thus possadha together with pratijagrati/pratijägarti may be rendered as 'to keep the uposatha'. Now let us return to the phrase 'uposatham upavasanti patijaggar[e/o/a]nti' in the Pali sutta. Of the three readings, patijaggaranti (plural form of patijagarati) seems the closest to pratijāgrati in Sanskrit. ${ }^{35}$ It could be that both upavasanti and patijāgaranti govern the noun uposatham, and patijagaranti appears to be a synonym for the preceding verb upavasanti. Therefore, uposatham upavasanti patijagaranti may be translated as '[they] observe and keep the uposatha'.

${ }^{33}$ A noun in the accusative, äpattiñ (happening, entering into a state, offence, etc.; see BHSD 97, MW 142, SJD 197), does not seem to fit here and is left untranslated.

${ }^{34}$ BHSD 362 s.v. pratijāgarti, ${ }^{j} j \overline{a g a r a t i},{ }^{j} j \bar{a}$ grati ... (2) watches = guards. MW 665 s.v. prati- $\sqrt{j a \bar{a} g}$, P. $-j \bar{a} g a r t i$, to watch beside ... to keep (?).

${ }_{35}$ The third person plural form of pratijaggarti is pratijāgrati. See Kale (1972: 264). 


\subsection{Cultural Background}

Professor Richard Gombrich suggests that we should give due weight to the reference to keeping the uposatha, and that this gives us a clue that the whole little story is one which is rooted in the cultural background. Note that the uposatha was a preBuddhist custom. He explains:

The pre-Buddhist ceremony (which probably continued for many centuries after the Buddha) was theistic, and began on the day/evening before the main ritual. After some initial purificatory rites, the participants took a vow very much like the 8 precepts, which involved fasting, chastity, and abstention from entertainments and luxuries. They then spent the night awake in the shrine of the god who would preside over the central ritual (e.g., a $d \bar{\imath} k s \underline{\bar{a}}$ ) the next day. Abstention from sleep was thus part of the regime - and fitted in nicely after the abstention from comfortable beds. It is thus no coincidence that it is gods who are said to be making this inspection of the human world (Gombrich's e-mail, 4 July 2016).

In view of the historical and cultural background of the sutta passage in question, patijāgar[e/o/a]nti probably derives from the Sanskrit verb jāgarti (MW 417 s.v. $j$ jagr: to be awake or watchful), ${ }^{36}$ and may mean 'stay watchful', or 'keep the vigil' as translated by Woodward (1932: 126). If this is the case, the puzzling word might be a variation of patijaggati (PED 394 s.v. patijaggati [... cp. BSk. pratijāgarti ...]), ${ }^{37}$ which is equivalent or closely related to the Sanskrit word pratijāgarti discussed above, but here in the sense of an intransitive verb 'to stay awake or watchful'. ${ }^{38}$ Then pațijāgaranti (BHSD 362 s.v. pratijāgarti, 'jāgarati) is possibly the correct reading among the three variants in AN 3:37 and could be rendered as 'stay watchful', but not as 'stay awake'. This is because, unlike the pre-Buddhist ceremony quoted above, observance of the uposatha in Buddhism does not require staying awake all day and night. As the Buddha prescribes in AN 3:70, on an uposatha day the laity, following the example of arahants, keep eight precepts for one day and night. The eighth precept is: '... Today, for this night and day, I too shall abandon and abstain from the use of high and big beds; I shall lie down on a low resting place, either a small bed or a straw mat ...' (translation mostly follows Bodhi 2012: 300). Therefore, observance of the uposatha allows people to sleep without having to stay awake all the time.

${ }^{36}$ I am grateful to Dr. William Pruitt for this suggestion.

${ }^{37}$ Cf. PED 277 s.v. jaggati $[=$ jāgarati ...]. The simplex Sanskrit jāgarti/jāgrati could develop into Pali in two ways, either by assimilation jāgrati > jaggati, or by insertion of a thema vowel jāgarti $>j \bar{a} g a r-a-t i$. I thank an anonymous reader for this explanation. awake (opp. sleeps).

${ }^{38}$ BHSD 362 s.v. pratijāgarti, ${ }^{\circ} j a \bar{g} g a r a t i,{ }^{\circ} j a \overline{g r a t i} \ldots$... Pali patijaggati ... (1) watches $=$ stays 


\subsection{A Perspective from Textual History}

This sutta passage in AN 3:37 has at least seven Chinese parallels. Among these parallels, SĀ2 46 (T II 389a) is too different from the Pali to be compared. The other six versions have words equivalent (or similar) to 'behave properly towards their mother and father, behave properly towards ascetics and brahmins, honour the elders of the family, observe the uposatha, patijāgar[e/o/a]nti, and make merits' in the Pali version. Below are the six parallel versions extant in Chinese translations (phrases in italics are not found in the Pali):

(1) Sütra 1117 of the Samyukta Ägama (T 99) translated by Gunabhadra (between 435 and 443 CE, see Section 5):

make offerings to their father and mother, to ascetics and brahmins, respect their clansmen, make various merits, see faults in this world, fear suffering in the world beyond, practise giving, make merits, observe the uposatha (lit. observe fasting and precepts).

T II 295c: 供養父母、沙門、婆羅門, 宗親尊重, 作諸福德, 見今世惡, 畏後世 罪, 行施, 作福, 受持齋戒。

(2) Sütra 30 of the Dìrgha Ägama (T 1) translated by Buddhayaśas 佛陀耶舍 and Zhu Fonian 竺佛念 (413 CE) (Lü 1963: 242):

pay reverence to their father and mother, respect ascetics and brahmins, honour the elders, observe the uposatha (lit. keep precepts and observe fasting), give to the poor.

T I 134b: 孝順父母, 宗敬沙門、婆羅門, 恭順長老, 持戒守齋, 布施躬乏。

(3) Sütra 6 in Chapter 24 of the Ekottarika Agama (T 125) translated by Dharmanandi 昙摩難提 and Zhu Fonian $(358 \mathrm{CE})^{39}$ :

pay reverence to their father and mother, to ascetics and brahmins, respect the elders, like giving, observe the uposatha (lit. observe the eight precepts and fasting).

T II 624c-625a: 孝順父母、沙門、婆羅門, 及尊長者, 好喜布施, 持八關齋。

(4) The Loutan jing 樓炭經 (T 23) translated by Fali 法立 and Faju 法炬 (who worked together during 290-311) (FD 3343):

pay reverence to their father and mother, to ascetics and religious practitioners, respect the elders, observe the uposatha (lit. fasting and precepts), give, believe in this world and the world beyond.

T I 298b: 孝順父母、沙門、道人, 敬長老, 齋戒, 布施, 信今世、後世。

$(5,6)$ The Qishi jing 起世經 (T 24) translated by Jñānagupta 闍那崛多 (523-600) (FD 6530) and the Qishi yinben jing 起世因本經 (T 25) translated by Dharmagupta 達摩等多 (?-619) (FD 5670) have almost identical wording:

${ }^{39}$ For the translators and translation date, see the Preface to the translation of the Ekottarika $\bar{A}$ gama by Dao'an 道安 (T II 549a). The Taishō edition wrongly attributes it to Gautama Saṃghadeva 翟雲僧伽提婆. Cf. Palumbo (2013: 38-84). 
[T I 347a: Are there people in the world who practise / T I 402a: Are there human folk in the world who frequently practise] paying reverence and offerings to their father and mother, respect ascetics and brahmins? Honour the elders? Practise giving, keep the abstinence $\left({ }^{*} v\right.$ rata)? Observe the uposatha (lit. 'Guard the eight precepts, observe the six fasting [days]')?

[T I 347a: 於世間中頗亦有人修行 / T I 402a: 頗有人輩於世間中多行] 孝順、供 養父母, 恭敬沙門、婆羅門不? 於諸尊長崇重以不? 修行布施, 受禁戒不? 守 攝八關，持六齋不?

We should not play down the importance and authenticity of these Chinese translations from the Indic originals in that five out of the six were translated by different Indian individuals who could not have misunderstood their own culture, while one was translated by two Chinese monks. All the six Chinese versions have 'observe the uposatha' and '[practise] giving', which are preceded by a passage like 'behave properly towards their mother and father, behave properly towards ascetics and brahmins, honour the elders of the family' as found in the Pali version. This is not a mere coincidence, since these texts come from different traditions, which trace their origins back to a common source. The Samyukta Agama in Chinese translation is ascribed to the Mūlasarvāstivāda tradition (see above). The Chinese Dīrgha Āgama is widely attributed to the Dharmaguptaka (Lü 1963: 242; Kumoi 1963: 248; Ui 1965: 135; Waldschmidt 1980: 136; Akanuma 1981: 34f.; Mayeda 1985: 97; Salomon 1999: 173f.; Karashima 2014). Many scholars ascribe the Chinese Ekottarika Ägama to the Mahāsāṃghika (Ui 1965: 137f.; Akanuma 1981: 37-39; Bronkhorst 1985: 312-314; Pāsādika 2010: 88-90). I have also argued that this text is most likely to be of Mahāsāṃghika provenance (Kuan 2013a; 2013b).

As for the Loutan jing (T 23), Willemen (2008: 61) says: 'Loutan is a Prākrit form of Lokasthana'. This is attested in a passage in Kumārajīva's translation of the *Mahāprajñāpāramitā Upadeśa (Dazhidu lun 大智度論, T 1509) and a note (small words in brackets) inserted into it: '... among the six-division Abhidharma, the third division with eight chapters entitled *Loka-sthāna-prajñapti Division [this is the Loutan jing, being the third division of the six divisions] was composed by Maudgalyāyana. ${ }^{40}$ The canonical Abhidharma of the Sarvāstivāda comprises seven texts, namely the Jñannaprasthāna known as the 'body' and the other six texts called the 'six feet' (Hirakawa 1990: 131). The Jñanaprasthāna 發智, the 'body', is mentioned in the *Mahāprajñāparamitā Upadeśa just before the passage quoted above, while the foregoing 'six-division Abhidharma' evidently refers to the 'six feet'. Frauwallner (1995: 36) also confirms that the paragraph containing this passage deals with the Sarvāstivāda Abhidharma. Therefore, the Loutan jing is affiliated with the Sarvāstivāda according to the note inserted in this passage of the *Mahāprajñāpāramitā Upadeśa.

In summary, among the six Chinese versions, the Samyukta Agama version belongs to the Mūlasarvāstivāda, the Dìrgha Āgama version belongs to the Dharma-

${ }^{40} \mathrm{~T}$ XXV 70a: 六分阿昆曇中, 第三分八品之名〈分別世處分〉 [此是《樓炭經》, 作 六分中第三分]是目胖連作。 
guptaka, the Loutan jing version belongs to the Sarvāstivāda, and the Ekottarika Āgama version probably belongs to the Mahāsāmghika. The Qishi jing and Qishi yinben jing versions are unclear regarding their school affiliations. Just like the present Theravāda school (using Pali), the Dharmaguptaka, the Sarvāstivāda and the Mūlasarvāstivāda were all descended from the Sthaviras, opposed to the Mahāsāmghikas at the first schism, according to the sources of various schools. ${ }^{41}$ It is reasonable to assume a common 'ancestral' text from which these four versions of Sthavira origin are derived. Since the three Sthavira versions, i.e. those of the Dharmaguptaka, the Sarvāstivāda and the Mūlasarvāstivāda, all have 'observe the uposatha' alongside '[practise] giving', it is most likely that the Theravāda's version (AN 3:37) also had the same. If the Ekottarika Ägama version really belongs to the Mahāsāmghika, then the pre-schism text surely had a string of phrases containing 'observe the uposatha' and '[practise] giving'. Therefore, the Pali version 'observe the uposatha, patijāgar[e/o/a]nti' must come from the same phrases. In either case mentioned above, the word patijāgar[e/o/a]nti corresponds to '[practise] giving'. I venture to speculate that patijāgarenti, patijāgaronti and patijāgaranti could be corruptions of pariccāgam karonti, ${ }^{42}$ which sounds like patijāgaronti and may mean '[they] practise giving'. ${ }^{43}$ Even the Pali commentary associates -garonti with karonti (see above). An original *pariccāgam karonti could be the source of the otherwise quite unexplainable $o$ in the variant patijāgaronti, which could become the regular patijāgaranti through normalisation. ${ }^{44}$ The Sanskrit counterpart of pariccāgam karoti, namely parityāga $\sqrt{k r}$, is attested in several Buddhist texts such as the Mahāvastu, the Saddharmapundarīka Sütra and the Divyāvadāna. ${ }^{45}$

\section{Acknowledgements}

I am indebted to Dr. William Pruitt for reading an earlier draft of this paper, offering valuable suggestions and improving its English. My thanks are also due to Professor Richard Gombrich, Dr. Margaret Cone, Dr. Roderick S. Bucknell, Dr. Ligeia Lugli, Dr. Alice Collett and the two reviewers for varied help.

${ }^{41}$ For the references, see Kuan (2013b: 614 note 35$)$.

${ }^{42}$ Such corruptions or confusions are not unusual in the Pali texts. Here are two examples. While Ee I 142, 20 and Se I 181, 20 read khemappattā, Ce I 260, 7 reads khoppamattā, and Be I 141, 7 reads appamattā. While Ee I 254, 8 and Se I 330, 3 read nihitam ninnītakasāvam, Ce I 452, 17 reads nihitam nikkhittakasāvam, and Be I 255, 17 reads niddhantakasāvam. Different editions have divergent readings that even vary in the number of syllables.

${ }^{43}$ PED 425 s.v. pariccāga: giving (to the poor), liberality.

${ }_{44}^{44}$ am grateful to the first reviewer for this suggestion.

${ }^{45}$ E.g. Mvu II 112: parityāgam kṛtvāa; SPS 240: ātmabhāva-parityāgāmins ca karoti; Divy 104.030: parityāgah kriyatām. 


\section{Abbreviations}

References to Pali texts are to the Pali Text Society editions, unless otherwise stated.

$\mathrm{AN}=$ Anguttara Nikāya.

$\mathrm{Be}=$ Burmese edition. The Añguttara Nikāya I-III, Chațthasañgītipițakam. Pāḷi Series 15-17. Yangon: Ministry of Religious Affairs, 2008.

BHSD = Buddhist Hybrid Sanskrit Grammar and Dictionary, Volume II: Dictionary. Edited by Franklin EDGERTON, 1953. Delhi: Motilal Banarsidass, reprint 1993.

BHSG = Buddhist Hybrid Sanskrit Grammar and Dictionary, Volume I: Grammar. Edited by Franklin EDGERTON, 1953. Delhi: Motilal Banarsidass, reprint 1993.

BSk. $=$ Buddhist Sanskrit.

CBETA = CBETA Chinese Electronic Tripitaka Collection, Version 2014. Taipei: Chinese Buddhist Electronic Text Association.

$\mathrm{Ce}=$ Sinhalese edition. The Añguttara Nikāya I-VI, Buddha Jayanti Tripitaka Series, Vols. 18-23. Published under the patronage of the Government of Ceylon, 1960-1977.

$\mathrm{CST}=$ Chațtha Sañgāyana Tipițaka . Version 4.0 (digital version). Igatpuri: Vipassana Research Institute.

Divy $=$ Divyāvadāna . An electronic version based on the edition by L. VAIDYA, Mithila, 1959, input by Kensuke Окамото, Ryukoku University. (http:/gretil.sub.uni-goettingen.de/gretil/ 1_sanskr/4_rellit/buddh/divyav_u.htm, last access: 9 May 2018.)

DOP I $=\bar{A}$ Dictionary of Pāli, Part I. Edited by Margaret CONE. Oxford: Pali Text Society, 2001.

DOP II = A Dictionary of Pāli, Part II. Edited by Margaret CONE. Bristol: Pali Text Society, 2010.

$\mathrm{EDC}=$ The Encyclopedic Dictionary of the Chinese Language 中文大辭典. Edited by LiN Yin 林尹 and GAO Ming 高明. Taipei: Chinese Culture University, 1973.

$\mathrm{Ee}=$ European edition, i.e. Pali Text Society edition, of the Anguttara Nikāya.

FD = Foguang Da Cidian 佛光大辭典 (Foguang [Buddhist] Dictionary). Edited by CIYI 慈怡. Kaohsiung: Foguang Chubanshe, 1988.

$\mathrm{MN}=$ Majjhima Nikāya.

$\mathrm{Mp}=$ Manorathapūrañi (Commentary on the Anguttara Nikāya).

$\mathrm{Mvu}=$ Mahāvastu . An electronic version of the Mahāvastu-Avadāna based on the edition by Émile SENART, 3 vols., Paris 1882-1897, input by Emmanuel FAURÉ (formerly Université Marc Bloch, Strasbourg), under the supervision of Prof. Boris OGUIBÉNINE. Data conversion in cooperation with Stefan BAUMS, Seattle. (http://gretil.sub.uni-goettingen.de/gretil/1_sanskr/ 4_rellit/buddh/mhvastuu.htm, last access: 9 May 2018.)

MW = A Sanskrit-English Dictionary. Edited by Monier Monier-Williams. Oxford: Clarendon Press, 1899.

PED = The Pali Text Society's Pali-English Dictionary. Edited by T. W. RHYS DAVIDS and William STEDE. London: Pali Text Society, reprinted 1986. (First published 1921-1925.)

$\mathrm{S} \overline{\mathrm{A}}=$ Samyukta Aggama (Za ahanjing 雜阿含經).

$\mathrm{SA} 2=$ Other Translation of the Samyukta Āgama (Bieyi Za ahanjing 別譯雜阿含經).

$\mathrm{Se}=$ Siamese edition. The Ainguttara Nikāya I-V, Chulachomklao of Siam Pāli Tipitaka, Vols. 2024. Bangkok: King Chulalongkorn, 1893.

$\mathrm{SJD}=$ Kan'yaku taishō Bon-Wa daijiten 漢訳対照梵和大辞典 (A Sanskrit-Japanese Dictionary with Equivalents in Chinese Trans-lation). Edited by WOGIHARA Unrai 荻原雲来, revised edition. Tokyo: Kōdansha, 1986.

$\mathrm{SN}=$ Samyutta Nikāya.

$\mathrm{Sn}=$ Sutta-nipāta (by verse). 
Spk = Sāratthappakāsinī (Commentary on the Samyutta Nikāya).

SPS $=$ Saddharmapundarīka Sūtra. An electronic version based on the edition by P. L. VAIDYA. Darbhanga: The Mithila Institute, 1960, input by members of the Sanskrit Buddhist Input Project. (http://gretil.sub.uni-goettingen.de/gretil/1_sanskr/4_rellit/buddh/bsu036_u.htm, last access: 9 May 2018.)

$\mathrm{T}=$ Taishō Shinshū Daizōkyō 大正新脩大藏經 (Taishō Edition of the Chinese Tripitaka). Edited by TAKAKUSU Junjirō 高楠順次郎 et al. Tokyo: Taishō Issaikyō Kankōkai, 1924-1934 (cited from CBETA).

Vibh-a = Sammohavinodanī (Vibhanga-ațthakathā $)$.

Vism = Visuddhimagga of Buddhaghosācariya . Edited by Henry Clarke WARREN. Delhi: Motilal Banarsidass, reprint 1999. (First published Cambridge, Massachusetts: Harvard University Press, 1950.)

\section{References}

AKANUMA Chizen 赤沼智善 1981. Bukkyo kyōten shiron 佛教經典史論 [On the history of Buddhist texts]. Kyoto: Hōzōkan.

Allon, Mark 1997. Style and Function. A Study of the Dominant Stylistic Features of the Prose Portions of Pāli Canonical Sutta Texts and Their Mnemonic Function. Tokyo: The International Institute for Buddhist Studies of the International College for Advanced Buddhist Studies.

AnĀLAYO 2015. 'Brahmavihāra and Awakening, A Study of the Dīrgha-āgama Parallel to the Tevijja-sutta.' Asian Literature and Translation 3/4: 1-27.

AnĀLAYo 2016. 'A Brief Criticism of the "Two Paths to Liberation” Theory.' Journal of the Oxford Centre for Buddhist Studies 11: 38-51.

BingenheIMer, Marcus 2011. Studies in Ägama Literature. With Special Reference to the Shorter Chinese Samyuktāgama. Taipei: Shin Wen Feng Print Co.

BodHI, Bhikkhu (tr.) 2000. The Connected Discourses of the Buddha. A New Translation of the Samyutta Nikāya. Oxford: Pali Text Society.

BodHI, Bhikkhu (tr.) 2012. The Numerical Discourses of the Buddha. A Translation of the Anguttara Nikāya. Boston: Wisdom Publications.

Brockington, J. L. 1996. The Sacred Thread. [2nd edition] Edinburgh: Edinburgh University Press.

BRONKHORST, Johannes 1985. 'Dharma and Abhidharma.' BSOAS 48: 305-320.

Buswell, Robert E., Jr. and Donald S. Lopez, Jr. (eds.) 2014. The Princeton Dictionary of Buddhism. Princeton and Oxford: Princeton University Press.

DHAmmadinNĀ 2012. 'A Translation of the Quotations in Śamathadeva's Abhidharmakośopāyikāțik̄a Parallel to the Chinese Samyukta-ägama Discourses 8, 9, 11, 12, 17 and 28.' Dharma Drum Journal of Buddhist Studies 11: 63-96.

ENomoto Fumio 榎本文雄 1984a. 'Setsu issai u bu kei Āgama no tenkai: Chū agon to Zō agon o megutte. 說一切有部系アーガマの展開——阿含』と『雜阿含』をめぐって [The development of the Āgamas of the Sarvāstivāda lineage: concerning the Madhyama Āgama and the Samyukta Ágama].' Journal of Indian and Buddhist Studies 32/2: 1073-1070.

ENOмото Fumio 榎本文雄 1984b. 'Agon kyōten no seiritsu 阿含經典の成立 [Formation of the Āgama texts].’ Tōyō gakujutsu kenkyū 東洋學術研究 23/1: 93-108.

FrAUWALlNER, Erich 1995. Studies in Abhidharma Literature and the Origins of Buddhist Philosophical Systems. [Trans. by Sophie Francis KIDD.] Albany, NY: State University of New York Press. 
GomBrich, Richard F. 2001. 'A Visit to Brahmā the Heron.' Journal of Indian Philosophy 29: 95108.

GOMBRICH, Richard F. 2009. What the Buddha Thought. London: Equinox.

Harvey, Peter 2013. An Introduction to Buddhism. Teachings, History and Practices. [2nd ed.] Cambridge: Cambridge University Press.

HeIM, Maria 2017. 'Buddhaghosa on the Phenomenology of Love and Compassion.' In: Jonardon GANERI (ed.) The Oxford Handbook of Indian Philosophy. New York: Oxford University Press, $171-189$.

von HINÜBER, Oskar 1997. A Handbook of Pāli Literature. [1st Indian ed.] New Delhi: Munshiram Manoharlal.

HiraKawa, Akira 1990. A History of Indian Buddhism. From Śākyamuni to Early Mahāyāna. [Trans. and ed. by Paul GRONER.] Honolulu: University of Hawaii Press.

HiRAOKA, Satoshi 2000. 'The Sectarian Affiliation of Two Chinese Samyuktāgamas.' Journal of Indian and Buddhist Studies 49/1: 506-500.

HIRAOKA Satoshi 平岡聡 2003. 'Zō agon kyō to setsu issai u bu no ritsuzō. 『雑阿含經』と說一 切有部の律藏 [The Samyukta Agama and the Vinaya of the Sarvāstivāda].' Journal of Indian and Buddhist Studies 51/2: 818-813.

Hu-von HinÜBer, Haiyan 1994. Das Poṣadhavastu. Vorschriften für die buddhistische Beichtfeier im Vinaya der Mūlasarvāstivādins. [Studien zur Indologie und Iranistik, Monographie 13.] Reinbek: Dr. Inge Wezler, Verlag für Orientalische Fachpublikationen. [An electronic version based on the above edition is available at URL: http://gretil.sub.uni-goettingen.de/ gretil/1 sanskr/4 rellit/buddh/vinv02 u.htm, last access: 9 May 2018.]

Hwang, Soonil 2006. Metaphor and Literalism in Buddhism. The Doctrinal History of Nirvana. London and New York: Routledge.

JoneS, John J. 1956. The Mahāvastu. Vol. III. London: Pali Text Society. [Repr. 1978.]

de JoNG, Jan W. 1981. 'Fa-hsien and Buddhist Texts in Ceylon.' Journal of the Pali Text Society 9: $105-115$.

KaLE, Moreshvar R. 1972. A Higher Sanskrit Grammar. [Repr.]. Delhi: Motilal Banarsidass.

KARASHIMA, Seishi 2014. 'The Sarvāstivādins' "Encroachment" into the Chinese Translation of the Daśottara-sūtra in the Dīrgha-āgama of the Dharmaguptakas.' In: DHAmmadinnĀ (ed.) Research on the Dìrgha-ägama. Taipei: Dharma Drum Publishing Corp., 197-235.

KuAn, Tse-fu 2013a. 'The Pavāraña Sutta and "Liberation in Both Ways" as against "Liberation by Wisdom".' BSOAS 76/1: 49-73.

KuAn, Tse-fu 2013b. 'Legends and Transcendence: Sectarian Affiliations of the Ekottarika Agama in Chinese Translation.' JAOS 133/4: 607-634.

Kumoi, Shōzen 1963. 'Āgama (2).' In: G. P. MalalaseKera (ed.) Encyclopaedia of Buddhism, Vol. I, Fasc. 2. n.p.: Government of Ceylon, 244-248.

LÜ, Cheng 1963. 'Āgama (1).' In: G. P. MalalaseKera (ed.) Encyclopaedia of Buddhism, Vol. I, Fasc. 2. n.p.: Government of Ceylon, 241-244.

MAYEDA, Egaku 1985. 'Japanese Studies on the Schools of the Chinese Āgamas.' In: Heinz BECHERT (ed.) Zur Schulzugehörigkeit von Werken der Hīnayāna-Literatur, Erster Teil. Göttingen: Vandenhoeck \& Ruprecht, 94-103.

Mizuno Kōgen 水野弘元 1996. Bukkyō bunken kenkyū 仏教文献研究 [A study of Buddhist literature]. Tokyo: Shunjūsha.

ÑāṆAMOLI, Bhikkhu (tr.) 1975. The Path of Purification. [3rd ed.] Kandy: Buddhist Publication Society.

ÑĀNamOLI, Bhikkhu and Bhikkhu BodHI (tr.) 2001. The Middle Length Discourses of the Buddha. [Revised ed.] Oxford: Pali Text Society. 
NoRman, Kenneth R. 2000. (tr.) The Word of the Doctrine. [Reprinted with corrections.] Oxford: Pali Text Society.

Norman, Kenneth R. 2004. 'On Translating the Suttanipāta.' Buddhist Studies Review 21/1: 69-84.

Norman, Kenneth R. 2006. A Philological Approach to Buddhism. The Bukkyō Dendō Kyōkai Lectures 1994. [2nd ed.] Lancaster: Pali Text Society.

NyAnATILOKa 1970. Buddhist Dictionary. Manual of Buddhist Terms and Doctrines. [3rd revised and enlarged ed.] Singapore: Singapore Buddhist Meditation Centre.

Olivelle, Patrick 1998. The Early Upanișads. Annotated Text and Translation. Oxford: Oxford University Press.

Palumbo, Antonello 2013. An Early Chinese Commentary on the Ekottarika-āgama. The Fenbie gongde lun 分別功德論 and the History of the Translation of the Zengyi ahan jing 增一 阿含經. Taipei: Dharma Drum Publishing Corp.

PĀSĀDIKA, Bhikkhu 2010. 'Gleanings from the Chinese Ekottarāgama Regarding School Affiliation and Other Topics.' In: Konrad MeIsIg (ed.) Translating Buddhist Chinese. Problems and Prospects. Wiesbaden: Harrassowitz Verlag, 87-96.

RahUla, Walpola 1959. What the Buddha Taught. Oxford: Oneworld Publications. [Repr. 2000.]

Rотн, Gustav (ed.) 1970. Bhikșuñ-Vinaya. Including Bhikṣuñi-Prakīnnaka and a Summary of the Bhikșu-Prakīnnaka of the Ārya-Mahāsāmghika-Lokottaravādin. Patna: K. P. Jayaswal Research Institute.

SALOMON, Richard 1999. Ancient Buddhist Scrolls from Gandhāra. The British Library Kharoșthī Fragments. Seattle: University of Washington Press.

Sharf, Robert H. 2002. Coming to Terms with Chinese Buddhism. A Reading of the Treasure Store Treatise. Honolulu: University of Hawaii Press.

Tin, Daw Mya (tr.) 1990. The Dhammapada. Verses and Stories. Delhi: Sri Satguru Publications.

Ui Hakuju 宇井伯壽 1965. Indo tetsugaku kenkyu (daini). 印度哲學研究 (第二) [A study of Indian philosophy, Vol. II.] Tokyo: Iwanami Shoten.

WALDSCHMIDT, Ernst 1980. 'Central Asian Sūtra Fragments and Their Relation to the Chinese Āgamas.' In: Heinz BECHERT (ed.) The Language of the Earliest Buddhist Tradition. Göttingen: Vandenhoeck \& Ruprecht, 136-174.

WANG Jui-Hsiang 王瑞鄉 2008. Chuqi fojiao ci, bei, xi, she de xiuxi yu jietuo zhi jian de guanxi一xiangguan jingzheng zhi zhengli yu yanjiu 初期佛教慈悲喜捨的修習與解脫之間的 關係——相關經證之整理與研究 [The relationship between kindness, compassion, sympathetic joy, equanimity and liberation in early Buddhism_ — an arrangement and study of the relevant sūtras]. (MA thesis, Chung-Hwa Institute of Buddhist Studies.)

WiLLEMEN, Charles 2008. 'Kumārajīva's "Explanatory Discourse" about Abhidharmic Literature.' Journal of the International College for Postgraduate Buddhist Studies 12: 37-83.

Woginara Unrai 荻原雲來 (tr.) 1935. Nanden Daizōkyō, dai 17 kan, Zōshibu Kyōten, I 南傳大 藏經第十七卷 增支部經典一 [The Southern Canon, Vol. 17: Texts of the Anguttara Nikāya, I]. Tokyo: Taishō Shinshū Daizōkyō Kankōkai.

Woodward, Frank L. (tr.) 1932. The Book of the Gradual Sayings, Vol. I. Oxford: Pali Text Society. [Repr. 2000.]

Woodward, Frank L. (tr.) 1933. The Book of the Gradual Sayings, Vol. II. Oxford: Pali Text Society. [Repr. 2001.]

YINSHUN 印順 1994. Yuanshi fojiao shengdian zhi jicheng 原始佛教聖典之集成 [Compilation of the original Buddhist scriptures]. [3rd revised ed.] Taipei: Zhengwen Chubanshe. 
